\title{
PERBANDINGAN TINGKAT STRES MAHASISWA KEPERAWATAN PROGRAM TRANSFER SEMESTER I DAN SEMESTER III DALAM MENGIKUTI SISTEM PEMBELAJARAN BLOK
}

\author{
Ozafina Martaviani*, Yufitriana Amir, Yesi Hasneli \\ Program Studi Ilmu Keperawatan, Universitas Riau, Jl. Pattimura, Cinta Raja, Kec. Sail, Kota Pekanbaru, Riau, \\ Indonesia 28127 \\ *ozafina27@gmail.com
}

\begin{abstract}
ABSTRAK
Tingkat stres yang dialami mahasiswa keperawatan program transfer selain kuliah sambil bekerja, mahasiswa juga dituntut untuk bisa menyesuaikan diri dengan sistem pembelajaran blok yang digunakan dalam proses pembelajaran. Penelitian ini bertujuan untuk mengetahui perbedaan tingkat stres mahasiswa keperawatan program transfer semester I dan semester III dalam mengikuti sistem pembelajaran blok di Fakultas Keperawatan Universitas Riau dengan desain penelitian deskriptif komparatif dan pendekatan cross sectional. Sampel penelitian adalah 81 orang yang diambil dengan mengunakan sampling jenuh.Alat ukur yang digunakan adalah kuesioner untuk variabel tingkat stres yaitu Depression Anxiety Stress Scala 42 (DASS 42). Analisa yang digunakan adalah analisa univariat untuk mengetahui distribusi frekuensi dan bivariat menggunakan uji man-whitney. Hasil penelitian menunjukkan bahwa responden dengan umur 17-25 tahun sebanyak 54 orang $(66,7 \%)$, jenis kelamin perempuan sebanyak 59 orang $(72,8 \%)$ dan hampir seluruh responden tidak bekerja sebanyak 60 orang $(74,1 \%)$. Hasil uji statistik diperoleh $p$ value $(0,02)<\alpha(0,05)$. Hasil penelitian ini diketahui bahwa terdapat berbedaan signifikan antara tingkat stres mahasiswa program transfer semester I dan semester III dalam mengikuti sistem blok di Fakultas Keperawatan Universitas Riau.
\end{abstract}

Kata kunci: mahasiswa, sistem blok, tingkat stres

\section{THE COMPARISONS OF STRESS LEVELS IN FIRST AND THIRD SEMESTER STUDENTS OF TRANSFER PROGRAM TAKING PART IN BLOCK LEARNING SYSTEM}

\begin{abstract}
Stress levels among students of nursing department of transfer program are affected by not only having to work while studying but also adapting with block learning system that is used for their learning process. This study aimed at determining the comparisons of stress levels in first and third semester students taking part in block learning system at Nursing Faculty of University of Riau. It was a quantitative study using descriptive comparative design with cross sectional approach. A total sample of 81 participants for this study was selected using saturated sampling technique. The research instrument was questionnaire, with Depression Anxiety Stress Scala 42(DASS 42) applied to determine stress level variables. The univariate analysis was employed to determine frequency distribution, while the bivariate analysis used Mann Whitney test. The result depicted that 54 respondents $(66.7 \%)$ were the age of $17-25$, while 59 respondents $(72.8 \%)$ were female, and almost all of the respondents 60 individuals, (74.1\%) were not student-workers. The statistic test results showed that the $p$ value was of $(0.02)<\alpha(0.05)$. The result that there were significant differences in stress levels between the first and third semester students taking part in block learning system at Nursing Faculty of University of Riau.
\end{abstract}

Keywords: block curriculum system, stress levels, university students

\section{PENDAHULUAN}

Fakultas Keperawatan merupakan salah satu fakultas termuda di Universitas Riau. Awal berdirinya Fakultas Keperawatan didahului oleh Program Studi Ilmu Keperawatan (PSIK) dibawah naungan Fakultas Matematika dan
Ilmu Pengetahuan Alam (MIPA) kemudian resmi menjadi Fakultas Keperawatan pada tahun 2017. Fakultas Keperawatan terdiri dari dua program studi yaitu Program Studi Ilmu Keperawatan dan Program Studi Profesi Ners. Program Studi Ilmu Keperawatan terdiri dari dua, yaitu Program regular dan program non 
regular (transfer). Program non regular lebih dikenal dengan program transfer di Fakultas Keperawatan Universitas Riau (Profil Keperawatan Universitas Riau, 2018). Mahasiswa program transfer memiliki latar belakang yang berbeda baik dari usia, suku, agama, status perkawinan, pengalaman bekerja dan lain-lain. Variasi latar belakang yang berbeda-beda ini akan mempengaruhi cara pandang mahasiswa terhadap proses pembelajaran dan akan berpengaruh terhadap pencapaian hasil belajar (Sahputra, 2013).

Pembelajaran merupakan interaksi antara peserta didik dan tenaga pendidik di dalam suatu lingkungan pembelajaran, yang bertujuan merubah perilaku peserta didik kearah yang lebih baik dan bermanfaat.Berbagai macam sistem pembelajaran diterapkan di perguruan tinggi. Fakultas Keperawatan dalam proses pembelajaran menggunakan sistem blok sejak tahun 2012. Sistem blok adalah penggabungan jam studi pada pembelajaran yang tiap tatap muka satu mata ajar tiap sekali dalam seminggu hingga tuntas menjadi satu minggu penuh atau sampai selesai hingga pembelajaran tersebut selesai, dengan tolak ukur materi dapat tersampaikan secara maksimal dan sesuai dengan tuntutan kurikulum (Simbolon, 2015).

Sistem blok yang diterapkan dalam kurikulum Fakultas Keperawatan Universitas Riau meminta mahasiswa untuk menyelesaikan satu hingga lebih topik perkuliahan selesai dalam satu kali pertemuan, mahasiswa harus bertatap muka dengan dosen sebanyak 3 kali dengan jadwal perkuliahan selama 6-7 jam tiap harinya. Pemadatan waktu yang berkesinambungan antara materi, pratikum, atau penugasan sesuai dengan kompetensi yang harus dicapai mahasiswa (Profil Keperawatan Universitas Riau, 2018). Penerapan sistem blok menuntut mahasiswa untuk lebih mandiri dalam proses belajar mengajar, percepatan proses pembelajaran yang dilakukan tanpa mempertimbangkan kemampuan daya tangkap setiap mahasiswa berbeda. Tanggung jawab dan tuntutan kehidupan akademik pada mahasiswa dapat menjadi bagian stres yang dialami oleh mahasiswa (Sunarni, 2017).

Stres merupakan kondisi yang tidak menyenangkan dimana seseorang melihat adanya tuntutan diluar batas kemampuan.Keadaan stres dapat muncul apabila ada tuntutan yang luar biasa sehingga mengancam keselamatan atau integritas seseorang.Suatu stres dapat dikatakan "baik" atau "buruk" bergantung pada seberapa besar perasaan dan respon seseorang terhadap sumber stres tersebut (Marbun, 2018). Stresor adalah pemicu stres dalam kehidupan yang mengakibatkan terjadinya respons stres.Stresor dapat berasal dari berbagai kondisi baik fisik, psikologis, maupun sosial.Stres yang dialami mahasiswa bisa juga dipengaruhi oleh kegiatan mereka sehari-hari (Saam \& Wahyuni, 2013).

Hasil penelitian yang dilakukan oleh Simbolon (2015) tentang "Gejala Stres Akademis Mahasiswa Keperawatan Akibat Sistem Pembelajaran Blok Di Fakultas Ilmu Keperawatan X Bandung" pada 35 responden. Hasil penelitian menggambarkan bahwa mahasiswa yang mengikuti sistem belajar blok mengalami gejala-gejala stres akademis dalam kategori sering. Hasil penelitian Sunarti (2017) tentang "Analisis Tingkat Stres Mahasiswa Keperawatan Dalam Mengikuti Sistem Pembelajaran Blok" dengan 140 responden. Hasil penelitian ini memberikan beberapa simpulan jenis kelamin tidak memiliki hubungan yang berarti dengan tingkat stres, tingkat angkatan tidak memiliki hubungan yang berarti dengan tingkat stres, IPK tidak memiliki hubungan yang berarti dengan tingkat stres, dan sistem blok tidak memiliki hubungan yang berarti dengan tingkat stres.

Penelitian ini dilatar belakangi dari pengamatan peneliti berdasarkan proses belajar mengajar khususnya pada mahasiswa keperawatan program transfer yang menjalani sistem blok. Mahasiswa program transfer semester III awalnya berjumlah 46 orang menjadi 45 orang, salah satu dari mahasiswi mengundurkan diri pada pertengahan semester I sedang berlangsung mata kuliah blok Statistik. Berdasarkan pengamatan ini maka pada bulan Agustus 2019 peneliti memberikan pertanyaan kepada sepuluh orang mahasiswa keperawatan program transfer dengan tingkat angkatan berbeda. Peneliti memberikan beberapa pertanyaan terbuka terkait dengan tingkat stres mahasiswa akibat sistem blok. Peneliti mengkategorikan tingkat stres: normal, ringan, sedang dan berat berdasarkan jawaban mahasiswa, ditemukan bahwa delapan diantara mahasiswa mengatakan mengalami stres. Didapatkan empat mahasiswa semester I mengalami stres sedang, disebabkan karena mereka merasa tuntutan perkuliahan sangat 
banyak sementara waktu belajar sedikit, sedangkan empat mahasiswa semester III mengalami stres berat. Mahasiswa mengatakan walaupun sudah beradaptasi dengan lingkungan kampus. Skripsi menjadi salah satu ketakutan bagi mahasiswa karena selain menyusun skripsi mahasiswa juga menjalani blok seperti biasanya. Pikiran mahasiswa harus terbagi antara skripsi dan blok yang harus dijalani. Berdasarkan latar belakang tersebut, maka peneliti tertarik untuk melihat "perbandingan tingkat stres mahasiswa keperawatan program transfer semester I dan semester III dalam mengikuti sistem pembelajaran blok". Tujuan penelitian ini adalah untuk mengetahui perbandingan tingkat stres mahasiswa keperawatan program transfer semester I dan semester III dalam mengikuti sistem pembelajaran blok. Pentingnya dilakukan penelitian ini bagi mahasiswa keperawatan khususnya program transfer, diharapkan mahasiswa dapat mempersiapkan diri untuk membagi waktu dengan baik sehingga tidak mudah stres pada saat pembelajaran.

\section{METODE}

Penelitian ini dilaksanakan di Fakultas Keperawatan Universitas Riau yang dimulai dari bulan Agustus 2019 - Januari 2020. Jenis penelitian ini adalah penelitian yang bersifat kuantitatif menggunakan desain penelitian deskriptif comparative dengan rancangan penelitian cross sectional. Populasi dari penelitian ini adalah seluruh mahasiswa Keperawatan Fakultas Keperawatan Universitas Riau program transfer. Pengambilan sampel menggunakan teknik sampling jenuh dengan kriteria inkhlusi 2 kelompok yaitu 36 mahasiswa semester I dan 45 mahasiswa semester III.
Alat pengumpul data yang digunakan pada penelitian ini adalah kuesioner DASS 42 (Depression Anxiety and Stress Scale 42) untuk mengetahui tingkat stres mahasiswa semester I dan semester III dengan kategori normal, ringan, sedang dan berat. Penelitian ini menggunakan alat ukur yang sudah bakuCronbach Alpha sebesar 0.936, sehingga peneliti tidak menggunakan uji instrumen untuk mengetahui validitas dan reabilitas kuesioner tersebut. Analisa data menggunakan analisa univariat dan analisa bivariat.Analisa univariat mendeskripsikan karakteristik responden terkait umur, jenis kelamin dan pekerjaan. Analisa bivariat digunakan untuk mengetahui perbedaan signifikan tingkat stres mahasiswa keperawatan semester I dan semester III dalam mengikuti sistem blok dengan menggunakan uji alternatif Mann Whitney. Komite Etik Penelitian Keperawatan dan Kesehatan Fakultas Keperawatan Universitas Riau telah menelaah dengan teliti usulan penelitian dan menyetujui penelitian (Nomor: 14/ UN.19.5.1.8/KEPK.FKp/2019). Setelah mendapatkan surat persetujuan dari Komite Etik, peneliti mulai melakukan penelitian, selanjutnya peneliti menjelaskan maksud dan tujuan penelitian kepada responden, responden diminta untuk menandatangi lembar inform consent jika calon responden bersedia menjadi responden yang digunakan dalam penelitian ini, responden diminta untuk mengisi lembar kuesioner yang telah diberikan kemudian peneliti akan menggumpulkan kembali kuesioner yang telah diisi responden.

\section{HASIL}

Hasil penelitian disajikan pada tabel berikut.

Tabel 1.

Karakteristik responden $\left(\mathrm{n}_{1}=36, \mathrm{n}_{2}=45\right)$

\begin{tabular}{lcccccc}
\hline \multirow{2}{*}{ Karakteristik } & \multicolumn{2}{c}{ Semester I } & \multicolumn{2}{c}{ Semester III } & \multicolumn{2}{c}{ Jumlah } \\
\cline { 2 - 7 } & $\mathrm{f}$ & $\%$ & $\mathrm{f}$ & $\%$ & $\mathrm{f}$ & $\%$ \\
\hline Umur & 28 & 77,8 & 26 & 57,8 & 54 & 66,7 \\
$17-25$ & 6 & 16,7 & 12 & 26,7 & 18 & 22,2 \\
$26-35$ & 2 & 5,6 & 7 & 15,6 & 9 & 11,1 \\
$36-45$ & 5 & 13,9 & 17 & 37,8 & 22 & 27,2 \\
\hline Jenis Kelamin & 31 & 86,1 & 28 & 62,2 & 59 & 72,8 \\
Laki-laki & & & & & & \\
Perempuan & 23 & 63,9 & 37 & 82,2 & 60 & 74,1 \\
\hline Pekerjaan & 13 & 36,1 & 8 & 17,8 & 21 & 25,9 \\
Tidak Bekerja & & & & & & \\
Bekerja & & & & & & \\
\hline
\end{tabular}


Mayoritas mahasiswa yang berpartisipasi dalam penelitian ini adalah umur 17-25 tahun sebanyak $(66,7 \%)$ dengan jenis kelamin perempuan sebanyak $(72,8 \%)$ dan hampir dari keselurahan partisipan tidak bekerja sebanyak $(74,1 \%)$.

Tabel 2.

Tingkat stres responden $\left(\mathrm{n}_{1}=36, \mathrm{n}_{2}=45\right)$

\begin{tabular}{|c|c|c|c|c|c|c|c|}
\hline \multirow{2}{*}{ Tingkat Stres } & \multicolumn{2}{|c|}{ Semester I } & \multicolumn{2}{|c|}{ Semester III } & \multicolumn{2}{|c|}{ Jumlah } & \multirow{2}{*}{$P$ Value } \\
\hline & $\mathrm{f}$ & $\%$ & f & $\%$ & $\mathrm{f}$ & $\%$ & \\
\hline Normal & 6 & 16,7 & 1 & 2,2 & 7 & 8,6 & \\
\hline Ringan & 10 & 27,8 & 11 & 24,4 & 21 & 25,9 & 0,09 \\
\hline Sedang & 13 & 36,1 & 17 & 37,8 & 30 & 37,0 & \\
\hline Berat & 7 & 19,4 & 16 & 35,6 & 23 & 28,4 & \\
\hline
\end{tabular}

Frekuensi tingkat stres mahasiswa semester III lebih tinggi dibandingan dengan tingkat stres mahasiswa semester I. Mayoritas kategori tingkat stres mahasiswa semester III mengalami tingkat stres dalam kategori sedang dan berat.

Data tersebut menunjukkan bahwa tingkat stres memiliki hasil uji homogenitas dimana $\mathrm{p}$ value $(0,09)>\alpha(0,05)$ yang berarti tingkat stres memiliki data homogen dilakukan dengan menggunakakan uji Levene Test.

Tabel 3.

Uji normalitas data kuesioner tingkat stres pada mahasiswa semester I dan semester III $\left(\mathrm{n}_{\approx} 81\right)$

\begin{tabular}{lccc}
\hline & Semester & $f$ & $P$ Value \\
\hline Semester I & & 36 & 0,02 \\
Semester III & & 45 & 0,00 \\
\hline
\end{tabular}

Uji normalitas data dari uji Shapiro wilk didapatkan hasil pada semester I data tidak berdistribusi normal dengan $p$ value $(0,02)<\alpha$ $(0,05)$ dan pada semester III data tidak berdistribusi normal dengan $p$ value $(0,00)<\alpha$ $(0,05)$. Uji statistik yang digunakan untuk melihat perbedaan tingkat stres mahasiswa program transfer semester I dan semester III dalam mengikuti sistem pembelajaran blok menggunakan uji alternatif menggunakan uji mann-whitney.

Tabel 4.

Perbedaan tingkat stres mahasiswa program transfer semester I dan semester III dalam mengikuti sistem pembelajaran blok $\left(\mathrm{n}_{\Perp} 81\right)$

\begin{tabular}{clccccc}
\hline Variabel & \multicolumn{1}{c}{ Semester } & $f$ & Mean & $S D$ & Min-Mak & P Value \\
\hline Tingkat & Semester I & 36 & 18,81 & 5,492 & $6-29$ & \multirow{2}{*}{0,02} \\
\cline { 2 - 7 } Stres & Semester III & 45 & 21,73 & 5,770 & $0-32$ & \\
\hline
\end{tabular}

Hasil uji mann-whitney didapatkan skor ratarata tingkat stres mahasiswa semester I adalah 18,81 dengan standar deviasi 5,492 serta tingkat stres responden terendah adalah 6 dan tertinggi 29, sedangkan rata-rata skor tingkat stres mahasiswa semester III adalah 21,73 dengan standar deviasi 5,770 serta tingkat stres responden terendah adalah 0 dan tertinggi 32 . Hasil uji statistik diperoleh $p$ value $(0,02)<\alpha$ $(0,05)$ sehingga Ho ditolak maka dapat disimpulkan bahwa terdapat perbedaan signifikan antara tingkat stres mahasiswa program transfer semester I dan semester III dalam mengikuti sistem blok.

\section{PEMBAHASAN}

Karakteristik Responden meliputi: umur, jenis kelamin dan pekerjaan

Hasil penelitian ini menunjukkan bahwa mayoritas responden berusia 17-25 tahun berada pada rentang usia remaja akhir. Hal tersebut terjadi karena kebanyakan responden dalam penelitian ini adalah mahasiswa yang langsung melanjutkan dari program diploma ke program sarjana.

Menurut Depkes RI (2009) usia 17-25 tahun yakni usia peralihan dimana terjadi tahap perubahan menuju dewasa, perpindahan satu tahap ketahap selanjutnya dengan berbagai situasi masalah yang terjadi serta mengalami perubahan baik emosi, tubuh serta perilaku. Masa remaja akhir ditandai dengan ciri-ciri aspek-aspek psikis dan fisiknya mulai stabil, 
meningkatnya berfikir realistis, memiliki sikap pandang yang sudah baik, lebih matang dalam menghadapi masalah, ketenangan emosi lebih bertambah, serta lebih mampu menguasai perasaan, dan organ reproduksi sudah matang (Saputro, 2017). Penelitian ini sebagian besar mayoritas responden berjenis kelamin perempuan.Hal ini dibuktikan dengan jumlah mahasiswa perempuan di Fakultas Keperawatan Universitas Riau setiap tahunnya jenis kelamin perempuan selalu lebih banyak dibandingkan laki-laki. Data didapatkan berdasarkan statistik mahasiswa Fakultas Keperawatan Universitas Riau Tahun 2019.

Perawat di Indonesia dominan dengan perempuan yang lekat dengan jiwa keibuanya.Sementara laki-laki dianggap kuat, rasional, dan perkasa.Muncul stigma di kalangan masyarakat bahwa yang menjadi perawat itu identik dengan kaum perempuan, sehingga muncul konsep gender yang dikonstruksikan secara sosial maupun kultural (Wulandari, 2012). Sifat-sifat ini yang banyak dimiliki oleh kaum perempuan yang menyebabkan orang beranggapan bahwa keperawatan dominan serta sesuai untuk kaum perempuan (Siswanto, 2014). Pada penelitian ini sebagian besar responden tidak bekerja.Hal ini dikarenakan banyaknya jumlah mahasiswa keperawatan yang baru menyelesaikan pendidikan diploma langsung melanjutkan pendidikan ke jenjang sarjana.

Mahasiswa program transfer lebih banyak yang tidak bekerja mereka juga mempunyai tantangan. Tantangan dapat berupa suatu keharusan namun beradaptasi dengan sistem pembelajaran yang digunakan dalam institusi pendidikan serta kemampuan membagi fokus dalam menyelesaikan tugas kuliah.Mahasiswa dituntut untuk dapat beradaptasi dengan lingkungan akademik, banyaknya tuntutan dari pihak akademik berpotensi menyebabkan stres pada setiap individu yang menjalaninya (Mardayanti, 2019).

\section{Frekuensi Tingkat Stres Responden}

Hasil penelitian ini menunjukkan mayoritas mahasiswa mengalami tingkat stres sedang, Mahasiswa semester III tingkat stresnya lebih tinggi dibandingkan dengan mahasiswa semester I. Hal ini dapat terjadi karena salah satunya akibat sistem pembelajaran yang diterapkan. Fakultas Keperawatan Universitas Riau khususnya program transfer menggunakan sistem blok dalam proses pembelajaran. Penerapan sistem blok membuat mahasiswa menjadi lebih menguras pikiran dan tenaga, dimana proses percepatan waktu pembelajaran antara teori, pratikum, deadline dan tugas kuliah harus tercapai sesuai dengan kompetensi. Proses percepatan pembelajaran tanpa memikirkan bahwa daya tangkap setiap mahasiswa berbeda. Sebagian besar responden yang diteliti mengalami tingkat stres dalam kategori sedang.Mahasiswa yang mengalami stres sedang disebabkan adanya mekanisme koping yang tidak efektif serta manajemen waktu yang kurang baik. Apabila mekanisme koping mahasiswa tidak baik maka akan berdampak buruk pada nilai akademik. Stres sedang berlangsung beberapa jam hingga beberapa hari (Potter \& Perry, 2010).

\section{Perbedaan tingkat stres mahasiswa program transfer semester I dan semester III dalam mengikuti sistem pembelajaran blok}

Berdasarkan hasil uji mann-whitney didapatkan bahwa terdapat perbedaan signifikan antara tingkat stres mahasiswa program transfer semester I dan semester III dalam mengikuti sistem blok. Peneliti berasumsi bahwa penyebab stres yang dialami responden semester III selain mereka harus kuliah sambil bekerja, hal ini dapat terjadi akibat sistem pembelajaran blok yang digunakan dalam proses pembelajaran sistem blok adalah penggabungan jam studi pada setiap tatap muka yang biasanya dilakukan dalam satu minggu sekali menjadi satu minggu atau lebih hingga pelajaran berakhir (Pratiwi, 2015). Pemadatan waktu pembelajaran dilakukan secara berkesinambungan antara teori, tutorial, pratikum dan ujian.Dalam waktu kurun seminggu mahasiswa diharuskan bertatap muka dengan dosen minimal 5-6 jam per hari.

Mahasiswa semester III juga dihadapkan dengan tugas akhir, serta harus melaksanakan kegiatan kukerta diwaktu yang bersamaan.Stres yang terjadi pada mahasiswa semester III dapat disimpulkan akibat tuntutan lingkungan akademik dan pengelolaan manajemen waktu yang tidak baik. Peneliti berasumsi bahwa penyebab stres yang dialami responden semester I adalah kegagalan dalam penyesuain diri dengan sistem pembelajaran blok, tugas terlalu banyak dan deadline tugas perkuliahan. Stres yang terjadi pada mahasiswa semester I dapat disimpulkan akibat adaptasi lingkungan dari institusi 
sebelumnya ke Fakultas Keperawatan Universitas Riau. Setiap responden akan memberikan reaksi stres yang berbeda pada stressor yang sama.

Respon dari stres dapat berdampak baik dan buruk tergantung dari mekanisme koping masing-masing individu. Stres yang baik (eustress) apabila seseorang mencoba memenuhi tuntutan untuk menjadikan orang lain maupun dirinya sendiri mendapatkan sesuatu yang berharga. Sedangkan stres yang buruk (distress) apabila seseorang tidak bisa memenuhi tuntutan diri sendiri maupun orang lain dan mengganggapnya sebagai sebuah ancaman (Nasir \& Muhith, 2011).

Hasil penelitian ini tidak sejalan dengan penelitian Sunarni (2017) yang mengenai analisis tingkat stres mahasiswa keperawatan dalam mengikuti sistem pembelajaran blok didapatkan hasil tidak ada hubungan yang signifikan antara sistem blok dengan tingkat stres. Perbedaan itu dilatar belakangi oleh responden yang berbeda, mahasiswa reguler lebih fokus dalam menerima pembelajaran sedangkan mahasiswa transfer fokusnya terbagi yang dipengaruhi oleh kegiatan seharihari. Ada mahasiswa transfer yang kuliah sambil bekerja, selain itu mahasiswa transfer juga harus beradaptasi dengan lingkungan akademik terutama sistem pembelajaran yang diterapkan. Mahasiswa transfer kebanyakan berasal dari kampus yang berbeda dengan menggunakan sistem pembelajaran yang berbeda juga.

Penelitian ini sejalan dengan penelitian yang dilakukan Agusmar (2019) tentang perbandingan tingkat stres mahasiswa angkatan 2015 dengan angkatan 2018 Fakultas Kedokteran Universitas Baiturrahmah didapatkan hasil terdapat perbedaan tingkat stres mahasiswa angkatan 2015 dan 2018. Beberapa faktor penyebab stres pada mahasiswa tingkat akhir adalah kegagalan dalam penyesuain diri, penumpukan beban kuliah, terjalin hubungan yang tidak baik antar kerabat dan orang terdekat, serta tidak mampu manajemen waktu dengan baik.

\section{SIMPULAN}

Hasil penelitian menunjukkan adanya perbedaan tingkat stres mahasiswa keperawatan semester I dan semester III dalam mengikuti sistem pembelajaran blok. Frekuensi tingkat stres mahasiswa semester III lebih tinggi dibandingkan mahasiswa semester I.

\section{DAFTAR PUSTAKA}

Agusmar, A.Y., Vany. A.T., \& Wahyuni, S. (2018). Perbandingan Tingkat Stres pada Mahasiswa Angkatan 2018 dengan Angkatan 2015 Fakultas Kedokteran Universitas Baiturrahmah (Vol. 02).https://doi.org/https://doi.org/10.3385 4/heme.v1i2.238.g188

Andryana, N. C. (2018). A comparative study of stress level in the first, second, and third year studentsof medical faculty of university of lampung.

\section{Depkes.(2009). Kategori Umur Menurut Depkes RI (2009).Departemen Kesehatan RI.}

Marbun, Agnes Putri, et al. (2017). Faktorfaktor yang Mempengaruhi Stres Mahasiswa Program Transfer Keperawatan yang Sedang Menyusun Skripsi.Researchgate, 1(1), 2-5.

Mardayanti, D. W. I. (2019). Kualitas tidur pada mahasiswa sl fisioterapi transfer 2017-2018 universitas muhammadiyah kualitas tidur pada mahasiswa sl fisioterapi transfer 2017-2018 universitas muhammadiyah.

Nasir, A., \& Muhith, A. (2011).Dasar dasar keperawatan jiwa pengantar dan teori.Jakarta: Salemba Medika.

Potter, Patricia A.; Perry, A. G. (2010).Fundamental of Nursing Seventh Edition.In Elsevier.

Pratiwi, P. kartika. (2015). Hubungan Penerapan jam pembelajaran sistem blok dan minat belajar dengan prestasi belajar mata pelajaran teknik kerja bengkel siswa kelas $\mathrm{X}$ smkn 1 magelang tahun ajaran 2013/2014. UNY.

Saam, Z., \& Wahyuni, S. (2013). Psikologi keperawatan. Jakarta: Rajawali Pers.

Sahputra, N. (2011). Hubungan Konsep Diri dengan Prestasi Akademik Mahasiswa S1 Keperawatan Semester III Kelas Ekstensi 
PSIK FK USU Medan Universitas Sumatera Utara.Jurnal Keperawatan.

Saputro, Z. khamim. (2017). Aplikasia: Jurnal aplikasi ilmu-ilmu agama ( memahami ciri dan tugas perkembangan masa remaja). Jurnal Aplikasi Ilmu Ilmu Agama, Volume 17(No 1), 25-32.

Simbolon, I. (2015). Reaksi stres akademis mahasiswa keperawatan dengan sistem belajar blok di fakultas keperawatan $\mathrm{x}$ bandung. Jurnal Skolastik Keperawatan.

Siswanto, F., Erwin, \& Woferst, R. (2014).Faktor-faktor yang berhubungan dengan motivasi mahasiswa untuk melanjutkan profesi ners.JOM PSIK.

Theresia Sunarni, Husaini, A., \& Pratama, Y. D. (2017). Analisis Tingkat Stres Mahasiswa Keperawatan Dalam Mengikuti Sistem Pembelajaran Blok. SAINTEK: Jurnal Ilmiah Sains Dan Teknologi Industri.

Universitas Riau. (2018). Profil Keperawatan Universitas Riau.Retrieved from UNRI PRESS.website:

https://keperawatan.unri.ac.id/profil/

Wulandari, T. I. P. (2012). Faktor-faktor yang melatarbelakangi laki-laki berprofesi sebagai perawat.Jurnal Eprint UNY, 66, 37-39. 
Jurnal Keperawatan Jiwa Volume 8 No 1 Hal 53 - 60, Februari 2020

FIKKes Universitas Muhammadiyah Semarang bekerjasama dengan PPNI Jawa Tengah 